\title{
Säädöstetty aikuiskoulutus yhdessä paketissa
}

\section{Ritva Jakku-Sihvonen - Pentti Yrjölä (toim.) 1994. Aikuiskoulutus 1990-luvun Suomessa. Opetushallitus. 551 sivua.}

Opetushallitus julkaisi1993 kahdentoista kirjasen sarjan "Suomalainen aikuiskoulutus". Nyt sisältöjä on saatettu ajan tasalle, materiaalia täydennetty parilla lisäartikkelilla ja kokonaisuus julkaistu yksissä kansissa. Tuloksena on muhkea, noin viisi ja puolisataa sivua käsittävä kuvaus aikuiskoulutuksen eri sektoreiden kehityksestä ja tilasta 1990-luvun alkupuolella. Muhkeudestaan ja nimestään huolimatta teos kattaa kuitenkin vain toisen puolen totuudesta, nimittäin valtion tuella toimivan aikuiskoulutuksen.

Selvityksen kirjoittajajoukko on runsas, kaikkiaan 30 enimmäkseen keskushallinnon virkamiestä. Niinpä eri osien esitystapa on epäyhtenäinen: pääasiassa tietankin kuivaa virkamiesproosaa, mutta kyllä joissakin artikkeleissa pilkahtaa pamflettimaista kannanottoakin. Ärsyttävää ja asiantuntematonta hämmentävää on se, että vaikka tekstejä onkin yhdenmukaistettu, edelleen eri artikkeleissa käsitteiden käyttö on epäyhtenäistä.

Kirja sisältää kuvauksen eri työmuotojen historiasta ja nykypäivästä sekä monien kohdalta pohdiskelua edessä olevista ongelmista. Lisäksi siinä on artikkelit aikuiskoulutuksen rahoituksesta, opettajien ja oppilaitosjohdon koulutuksesta sekä ajankohtaisista kehittämislinjoista. Lopussa on vielä keskeiset tilastot viime vuosien kehityksestä. Tilastot tosin poikkeavat eräiltä osin samoista asioista kertovista taulukoista itse tekstissä. Tämä on häiritsevää ja nakertaa tarpeettomasti viranomaisjulkaisun arvovaltaa.

Alkuperäistekstit on kirjoitettu ilmeisesti silloin, kun laman vaikutus aikuiskoulutukseen ei vielä ollut täysin selvillä. Muutenkin ala on kehittynyt toimitusvaiheen aikana niin, että tekstit ovat osittain vanhentuneita. Asiaa on pyritty korjailemaan lisäyksillä ja paikkauksilla, mutta eräiltä osin säädökset ovat ehtineet tehdä tekstin auttamattoman jälkeenjääneeksi (esim. pätevyystutkinnot). Olisi toivonut hieman perusteellisempaa tietojen uudistamista, kun esipuhe on kuitenkin päivätty niinkin tuoreeksi kuin 11.3.1994. Toisaalta aikuiskoulutus on edelleen niin dynaamisessa vaiheessa, ettei tällaista koko alueen kattavaa teosta kerta kaikkiaan voi saada aikaan niin, että siitä ei jokin osa olisi jo painokoneesta tullessaan vanhentunut.

Aikuiskoulutuksen nykyinen monimuotoisuus ja kattavuus tulee kirjassa erinomaisesti esille. Nyt jokainen aikuiskouluttaja voi todeta, että viulu on, kunhan vain (o)saisi soittaa. Organisaatio on luotu, nyt kaivataan soveltajia. Itse asiassa tämä monimuotoisuus on vielä huomattavasti suurempaa kuin mitä byrokratian rajanvedoista, luokituksista ja käsitteistöstä voisi päätellä. Lähes jokaisen luokittelun ja yleisperiaatteen kohdalla jää miettimään todellisuuden kirjavuutta malliin "Niin, mutta..", 'Ja lisäksi..." tai "iin, paitsi..." Niinpä heti kirjan kolme ensimmäistä kuviota, jotka hyvin virallisen näköisinä ovat esittävinään valtion aikuiskoulutusrahoituksen jakautumista yleissivistävän, ammatillisen ja työvoimapoliittisen aikuiskoulutuksen välillä, kuvaavat kyllä jotakin, mutta eivät tätä jakaumaa. jokainen tietää sen, mikä kirjan tekstistäkin käy ilmi, että jako yleissivistävän ja ammatillisen aikuiskoulutuksen välillä ei kulje budjetin mukaan, ei edes opiskelijaryhmien mukaan, vaan vähintäänkin ryhmän sisällä. Työvoimapoliittinen aikuiskoulutus jää tässä jaossa omaksi omitukseksi alueekseen, joka ei olisi ammatillista eikä yleissivistävää.

Ei kirjaa varsinaiseksi lomalukemiseksi voi suositella yömyssyksi osittain kyllä. Koulutussuunnittelijoiden kapulakieli on joskus todella unettavaa: "Verkostoissa selkiintyy vähitellen eettisesti kestävä toiminta-ajatus jokaiselle osapuolelle, jolloin moniarvoinen ohjaus vaikuttaa tulostavoitteiden määrittelyyn ja ohjausprosesseihin." Taikka sitten opintokeskusten tarkoituspykälä, jossa "toiminta-ajatus" on ilmaistu niin sokkeloisesti, että lähinnä jää ihmettelemään, onko opintokeskuksilta toiminta loppumassa, kun tehtävä on ilmaistu noin hämärästi. 
Uuvuttavaa on myös tilastotietojen runsaus, varsinkin, kun tietää niiden nopeasti muuttuvan huiman kehityksen mukana. Mikä tarkoitus lienee esim. kesäyliopistojen kohdalla esittää otsikolla "valtionrahoitus eräissä aikuisoppilaitoksissa" oikein pylväsdiagrammina absoluuttisen markkamäärät selittämättä tai suhteuttamatta niitä mihinkään? Teos olisi kaiken kaikkiaan parantunut heittämällä pikkusälää kuormasta ja jättämällä tähän yhteyteen vain marginaalisesti kuuluvat opettajien ja oppilaitosjohdon koulutusta koskevat kappaleet pois. Samalla olisi voinut karsia eräitä tekstien päällekkäisyyksiä.

Jotakin olisi toki kaivannut lisääkin. Kun vuosikymmenemme on vieläkin vasta alkupuolella, odotin, että teoksessa nimeltä "Aikuiskoulutus 1990-luvun Suomessa" käsiteltäisiin perusteellisemmin haasteita, jotka aikuiskoulutuksella on vielä tällä vuosikymmenellä edessään. Aivan keskeinen vielä tällä vuosikymmenellä ratkaistava ongelma on runsaiden ja monimuotoisten aikuiskoulutuspalvelujemme käytön tehostaminen ja koordinointi. Se vaatii aivan uutta panostusta neuvontaan, ohjaukseen ja opintosuunnitteluun. Ohjausta eivät tarvitse vain opiskelijat, vaan ensi vaiheessa nimenomaan eri aikuiskoulutusorganisaatiot ja yhteiskunnan tuki- ja neuvontapalvelut. Tätä tarkoitusta palvelee myös omalta osaltaan julkaistu teos.

Monimuoto-opiskelu, kansainvälistyminen, aikuisten opintotuki, aikuiskoulutuksen markkinointi ja vaikkapa suhteet työmarkkinoihin ovat teemoja, jotka tämän vuosikymmenen aikuiskoulutusesittelyssä olisin toivonut tulevan selkeämmin esiin vaikkapa historiallisten kehityskuvausten kustannuksella.

Ehkä myös omana lukunaan olisi voitu käsitellä aikuiskoulutuksen hallintoa ja sen kirjavuutta, mutta siinä olisikin jouduttu pohtimaan myös opetushallituksen olemassaolon mielekkyyttä, joten puheitta paras?

Kenelle teos sitten on tarkoitettu? Toimittajat sanovat tarkoittaneensa sen lähinnä "aikuiskoulutuksen parissa työskenteleville" ja opiskelijoille. (Opiskelijaparat: metsää ei ole helppo nähdä näin tiheiltä puilta.) Pikkupuutteistaan huolimatta pidän teosta tärkeänä ja toivoisin sen uudistamista vähintään pari kertaa vuosikymmenessä. Kirja sopii mielestäni erinomaisesti koulutussuunnittelijoiden, työvoima- ja kouluviranomaisten, neuvontatehtävissä toimivien ja tietenkin päätoimisten aikuiskouluttajien kirjahyllyyn. Miksipä ei myös poliittisille päättäjille - vaikkapa yöpöydälle.

Olavi Alkio 